Hydraulic Engineering Repository

Ein Service der Bundesanstalt für Wasserbau

Schuring, John R.; Dresnack, Robert; Golub, Eugene; Khan, Mohiuddin Ali;

Young, R.; Dunne, Richard; Aboobaker, Nazhat

Review of Bridge Scour Practice in the U.S.

Verfügbar unter / Available at:

https://hdl.handle.net/20.500.11970/100253

Vorgeschlagene Zitierweise / Suggested citation:

Schuring, John R.; Dresnack, Robert; Golub, Eugene; Khan, Mohiuddin Ali; Young, R.; Dunne, Richard; Aboobaker, Nazhat (2010): Review of Bridge Scour Practice in the U.S.. In: Burns, Susan E.; Bhatia, Shobha K.; Avila, Catherine M. C.; Hunt, Beatrice E. (Hg.): Proceedings 5th International Conference on Scour and Erosion (ICSE-5), November 7-10, 2010, San Francisco, USA. Reston, Va.: American Society of Civil Engineers. S. 1110-1119. 


\section{Review of Bridge Scour Practice in the U.S.}

John R. Schuring ${ }^{1}$, P.E., Member ASCE, Robert Dresnack ${ }^{2}$, P.E., Eugene Golub ${ }^{3}$, P.E., M. Ali Khan ${ }^{4}$, P.E., Member ASCE, Matthew R. Young ${ }^{5}$, Richard Dunne $^{6}$, P.E., Nazhat Aboobaker ${ }^{7}$, P.E., Member ASCE

${ }^{1}$ Professor of Civil and Environmental Engineering, New Jersey Institute of Technology, Newark, NJ 07102; Ph: 973-596-5849; schuring@njit.edu

${ }^{2}$ Professor of Civil and Environmental Engineering, New Jersey Institute of Technology, Newark, NJ 07102; Ph: 973-596-2469; dresnack@njit.edu

${ }^{3}$ Professor of Civil and Environmental Engineering, New Jersey Institute of Technology, Newark, NJ 07102; Ph: 973-596-2448; golub@adm.njit.edu

${ }^{4}$ Principal, Khan \& Associates, Moorestown, NJ 08057; Ph: 609-332-1136; malikhan@drmalikhan.com

${ }^{5}$ Research Assistant, New Jersey Institute of Technology, Newark, NJ 07102

${ }^{6}$ Deputy State Transportation Engineer, Bureau of Structural Engineering, NJDOT, Trenton, NJ 08648; Ph: 609-530-2557; Richard.Dunne@,dot.state.nj.us

${ }^{7}$ Project Manager, Bureau of Research, NJDOT, Trenton, NJ 08648; Ph: 609530-4491; Nazhat.Aboobaker@dot.state.nj.us

ABSTRACT: For years bridge designers in the U.S. have used FHWA Publication Hydraulic Engineering Circular No. 18 (HEC 18) as a principal tool to determine scour depths. Increasingly, though, practitioners recognize that some of the circular's standard equations over predict scour depth for certain geologic and hydraulic conditions. In an effort to improve scour design and evaluation methods, the New Jersey Department of Transportation (NJDOT) recently conducted a survey of current scour practice of DOTs across the U.S. The ten-question survey queried agencies about their design standards, experiences with failures, monitoring programs, and countermeasure preferences, among other things. This paper presents the results of the nationwide scour survey. Highlighted are the creative and diverse approaches by some states to either modify HEC 18 procedures or develop alternative scour prediction methods. The paper also discusses critical geologic, hydraulic, and hydrologic parameters for rational evaluation of scour depth, gleaned from both the survey and local experience with New Jersey bridges.

\section{INTRODUCTION}

Prevention of bridge scour has now been a national priority for two full decades. Beginning in 1990 with the Federal Highway Administration's (FHWA's) issuance of Technical Advisory T5140.20, transportation agencies across the U.S. have been deliberately engaged in evaluating the scour susceptibility of bridges within their inventories. Those bridges found to be scour critical are now in various stages of remediation, ranging from monitoring to outright replacement. While progress is being made, many state and county DOTs are still in the process of implementing their action plans. The reason is the sheer 
number of bridges that detailed screening has determined to be scour susceptible, which number into the hundreds in some states.

Prudent action is warranted, since scour remains a leading cause of bridge failure in the U.S. Fortunately, the large majority of the failures are not sudden or catastrophic. More commonly, the responsible agency observes progressive erosion and scour, and then decides to repair the bridge or replace it preemptively.

For riverine flow the principal scour tool for U.S. bridge designers is Hydraulic Engineering Circular No. 18 (HEC 18) published by the FHWA. Increasingly, though, practitioners recognize that the standard equations in HEC 18 over predict scour depth for certain hydraulic and geologic conditions. This is not surprising, since most of the HEC 18 relationships are based on laboratory flume studies conducted with sand-sized sediments. It is fair to ask whether scale modeling can effectively represent a phenomenon as complex as scour, especially in view of the wide diversity of hydrologic, hydraulic, and geotechnical conditions that exists across the nation. Indeed, the scour behavior of a bridge spanning a mile-wide river with silty sediments in the Midwest is quite different from a bridge crossing a boulder-filled stream in the Mountain States, which differs yet again from another bridge spanning a modest-size river choked with coarse glacial outwash in the Northeast. Recognizing such regional differences, and driven by the funding limitations, it is prudent to re-examine predictive scour models.

\section{BACKGROUND}

HEC 18 has been a key companion resource for FHWA's national scour program. Now in its fourth edition, HEC 18 remains in wide use by transportation agencies and consultants. The scour design relationships contained in the publication are an amalgamation of work by various investigators. For abutment scour, the principal relationship is the Froehlich Equation, which is based on a regression analysis of 170 laboratory flume tests (Froehlich, 1989). The alternative HIRE equation is also provided, and it is originally based on field data for scour at the end of spurs on the Mississippi River (Richardson, Simons, and Lagasse, 2001). Other methods for estimating abutment scour are also cited, including Sturm (1999) and Melville (1992). These are mostly based on laboratory flume testing as well.

The principal design relationship in HEC 18 for estimating pier scour is the CSU equation, which was derived from laboratory data by researchers at Colorado State University (Richardson, Simons, and Lagasse, 2001). Other relationships developed from laboratory flume testing are also cited but not specifically recommended, e.g. Laursen (1983) and Jain and Fischer (1979).

Without question, HEC 18 has served a worthy function in the nation's scour safety program by providing agencies and consultants with access to a compendium of design relationships. However, HEC 18 was never meant to be a mandate, but rather a guidance document that describes the "state of knowledge and practice." It does not preclude a transportation agency from applying another method of scour prediction as long as it is rational and defensible. 
A number of states have now opted to either modify the methods in HEC 18 or develop entirely new, alternate approaches for scour evaluation. Such efforts are typically backed by scientific studies that factor in the geologic and hydrologic conditions that exist within the respective state. An important motivation for these modified/alternate methods are the results of comparative field studies, which consistently show poor correlation between predicted scour using HEC 18 methods and actual scour observed in the field. And the disparity is becoming more apparent as the database of bridge inspection and monitoring data continues to expand.

\section{COMPARATIVE SCOUR STUDIES}

In recent years, several studies have compared the field scour observed at bridge sites with the scour values predicted by various equations. The studies reflect the ever increasing concern that current methods for estimating scour depth are principally based on laboratory experiments and do not necessarily correlate well with field conditions. These agencies are seeking more realistic procedures to estimate scour depth, since resources for construction and repair are chronically limited, and bridges need to be better prioritized so that funds are expended where they are truly needed.

Three recent comparative studies of bridge scour will be summarized in this section. All studies were rigorous, and in total they comprise more than 200 bridges located in five states.

\section{(1) Lombard, P.J. and G.A. Hodgkins (2008)}

This insightful study was recently completed by the U.S. Geological Survey (USGS) in cooperation with the Maine Department of Transportation. The investigators analyzed 50 bridges that were distributed geographically throughout the state. The median age of the bridges was 66 years, and all were single-span on non-tidal waterways. Field surveys were conducted to determine channel geometry and characteristics, as well as to measure observed abutment scour, which ranged from 0 to $6.8 \mathrm{ft}$. The average actual observed scour across all the sites was less than $1 \mathrm{ft}$. Skew angles of the abutments and embankments in relation to the channel showed wide variation, ranging from 0 to 50 degrees.

The four scour estimation methods applied to the bridges in the Maine study were the Froehlich/Hire method, the Sturm method, the Maryland Department of Transportation method, and the Melville method. A summary of the study results comparing predicted and observed scour are presented in Table 1. As indicated, no significant correlation was found between calculated scour and scour observed in the field for any of the four methods. In fact, predicted scour was frequently an order of magnitude greater than observed scour. Scour was also underpredicted by the equations $4 \%$ to $14 \%$ of the time. Given the lack of correlation between predicted and observed scour, the authors suggest it may be preferable to prescribe a single value of abutment scour and apply a suitable factor of safety. 
TABLE 1: Summary of Predicted vs. Observed Abutment Scour for Maine Study (modified from Lombard and Hodgkins, 2008)

\begin{tabular}{|l|ccc|ccc|c|}
\hline \multirow{2}{*}{ Method } & \multicolumn{3}{|c|}{ Overpredictions } & \multicolumn{3}{c|}{ Underpredictions } & Correl. \\
\cline { 2 - 7 } & $\%$ & Avg (ft) & Max (ft) & $\%$ & Avg (ft) & Max (ft) & Coeff. \\
\hline Froehlich & 96 & 10.8 & 33.2 & 4 & 2.2 & 3.9 & 0.00 \\
\hline Sturm & 86 & 8.4 & 50.9 & 14 & 5.5 & 17.7 & 0.01 \\
\hline MD DOT & 89 & 11.8 & 200.3 & 11 & 1.2 & 3.0 & -0.09 \\
\hline Melville & 86 & 4.3 & 21.3 & 14 & 1.4 & 3.2 & 0.08 \\
\hline
\end{tabular}

(2) Benedict, S.T, N. Deshpande, N. M. Aziz and P.A. Conrads (2006)

In this study the USGS in cooperation with the FHWA analyzed 144 bridges in South Carolina. Scour depth predictions were based on hydraulic conditions associated with 100-year flow at all sites and the flood of record at 35 sites. Five published scour equations were used to analyze each substructure including the original Froehlich equation, the modified Froehlich equation, the Sturm equation, the Maryland Department of Transportation equation, and the HIRE equation. Comparisons of predicted and observed scour for all bridge sites led the investigators to conclude that all five of the equations frequently over predicted scour depth, and at times excessively so. The investigators also reported on the difficulty of obtaining representative samples of bed sediment. They cautioned against the use of surface "grab" samples to characterize sediment grain size, suggesting soil borings instead.

(3) Wagner, C.R., D.S Mueller, A.C. Parola, D.J. Hagerty, \& S.T Benedict (2006)

This comparative scour study was conducted under the National Cooperative Highway Research Program (NCHRP), and its focus was 15 bridge sites located in the states of Minnesota, Montana, and South Dakota. The scour estimation equations applied to the studied bridges included the Sturm equation, the Froehlich equation, the modified Froehlich equation, and the HIRE equation. Upon comparing the predicted with the observed scour depths, the authors concluded that all methods were unreliable. Mostly, the scour equations over predicted scour depths, often by a factor of 2 to 40 times. However, under certain conditions predicted depths were less than observed depths. The authors cite the failure of laboratory research and one-dimensional models to capture the complexity of field conditions as the major reason for the unreliability of the predictive equations. 


\section{SCOUR PRACTICE SURVEY: DESIGN AND RESULTS}

During summer 2009, a Scour Practice Survey was sponsored by the New Jersey Department of Transportation (NJDOT) in an effort to assess the varied scour design and evaluation methods used by transportation agencies. The survey objectives were threefold: (1) to compile an updated summary of scour practice as related to HEC 18; (2) to query about modified or alternative methods for estimating scour depth; and (3) to identify potential best practices that might be adopted in New Jersey.

The ten-question survey was designed and administered by the New Jersey Institute of Technology (NJIT). It queried agencies about scour design standards, experiences with failures, monitoring programs and countermeasure preferences, among other things. In an effort to maximize response rate, participants were given the choice of several response modes, including direct on-line (to a server), email attachment, mailed hard copy, or any combination of these. Respondents were also encouraged to forward files and links describing local scour practice.

NJDOT distributed the survey to all the State Bridge Engineers via the AASHTO Bridge Committee network in late July 2009. Reponses began to accumulate on the NJIT server immediately. Over the next 60 days, response to the Practice Survey was notably strong with a total of 35 responses received, representing a nearly $70 \%$ response rate. Some respondents also forwarded failure data, photos, and design standards and specifications. The authors believe that the favorable response rate reflects, in part, a growing desire by states to seek alternatives for the analysis tools in HEC 18.

The results of the Scour Practice Survey are summarized in Table 2. The first question serves to confirm the breadth of the scour problem nationally, with $68 \%$ of agencies responding that they have had bridges fail due to scour, either by outright failure or by preemptive replacement. The most common type of scour erosion reported in the survey was local (23 responses), followed by meandering (17), contraction (16), debris (15), and degradation (14). Overtopping was reported by only six agencies as a problem. About $40 \%$ of the respondents indicate that they have installed fixed instrumentation to measure scour at abutments or piers, while only $17 \%$ have actually generated any summaries that compare predicted scour with field measurements. A similar number of agencies report that they have undertaken either field or laboratory measurement of erosion rates for soil or rock materials.

Among the most interesting result of the survey was the response to the Question 6, which asked whether there was a need to modify current HEC 18 design procedures. An overwhelming $79 \%$ of the agencies responded in the affirmative. Consistent with this response, nine agencies indicate that they are now using modified or alternative scour analysis methods for new bridges, while 11 states indicate that they employ modified/alternative analysis methods for existing bridges.

The final two questions provide insight about natural and artificial scour protection means currently in use. Slightly over half $(54 \%)$ of the agencies consider the effects of natural armoring in their scour computations. Natural 
TABLE 2: Summary of Scour Practice Survey Results

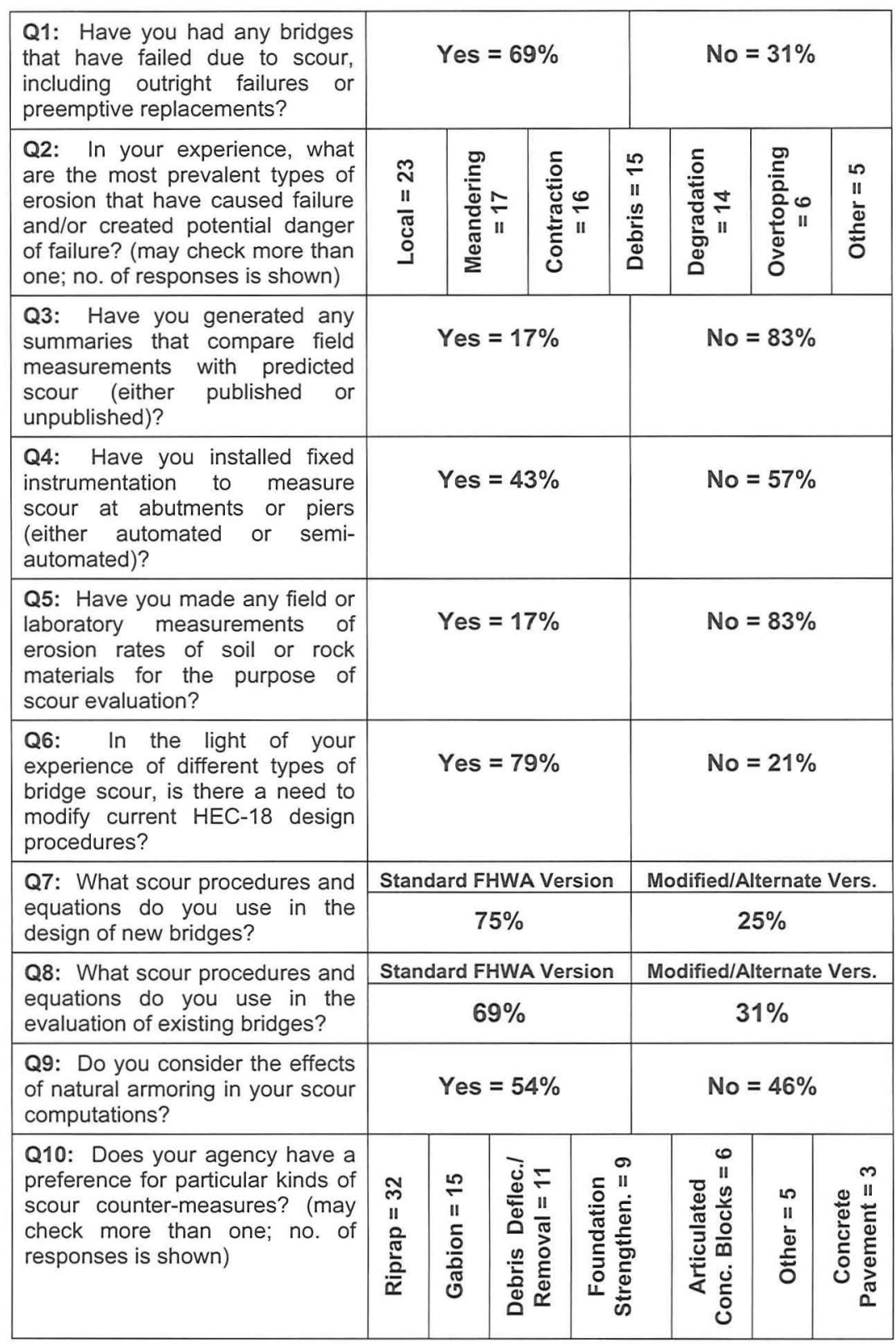


armoring occurs when a residual layer of coarse particles is exposed on the stream bed due to erosion and removal of fines. With regard to scour countermeasures, riprap remains the preferred choice by more than a 2:1 ratio. Gabions, debris deflection/removal, and foundation strengthening were the next most applied countermeasure methods. A small minority of the agencies report use of articulated concrete blocks, concrete pavement, or "other" methods.

Those states that are currently using modified or alternate scour analysis methods also generously furnished supporting documentation. In some cases, the method changes were for internal agency use only. These included: (1) use of 100-year flows for existing bridges as a maximum; (2) reduction of the factor of safety of the Froehlich equation; and (3) guided application of engineering judgment.

Other states have published formal design standards and/or rigorous scientific studies supporting their deviations from the standard methods in HEC 18. Selected examples of such modified or alternate scour analysis methods are listed and briefly described in Table 3. Reference links are also provided.

\section{NEW JERSEY'S SCOUR PROGRAM}

In 1990, NJDOT launched a robust statewide Scour Evaluation Program to assess the nearly 2,400 existing state and county highway bridges over waterways. Based primarily upon underwater inspection reports, the Stage I screening studies initially identified 313 state-owned bridges as potentially scour susceptible. In-depth Stage II scour evaluations were then carried out in four phases following the analysis procedures described in HEC 18. Upon completion of the Stage II evaluations, a total of 165 state bridges were determined to be scour critical.

In 2006, the Department launched a Plan of Action for the state's scour critical bridges. The Plan addressed corrective work for all scour critical structures, which is currently underway. The Plan also prescribed a new real-time flood monitoring program for bridges on the State Watch List to help safeguard the traveling public until corrective work was completed. The real-time monitoring program is Internet-based and is currently in operation. It is triggered by flood warnings and stream gauges located in the major watersheds around the state. Field crews are automatically dispatched to potentially affected bridges, and they are authorized to take preventive and/or corrective actions, as required. The realtime program is a cooperative effort between NJDOT's Structural Evaluation Group, Operations Group, and Regional Maintenance Engineers.

The Department has also recently engaged the USGS West Trenton Office to conduct erosion monitoring at selected scour critical bridges. These bridges, located along watercourses with high environmental sensitivity, have no history of observed scour and were placed on the critical list solely based on HEC 18 analysis methods. Assuming that no significant erosion is recorded over a several year period, consideration will be given to removal from the scour critical list.

A research study is also currently underway by NJIT to review and revise NJDOT's scour evaluation. Although the study is only about half-completed, the 
TABLE 3: Selected Examples of Modified or Alternative Scour Evaluation Methods across the U.S.

\begin{tabular}{|c|c|}
\hline State & Method Description \\
\hline Alabama & $\begin{array}{l}\text { This USGS Scientific Investigations Report published in } 2008 \text { provides an } \\
\text { alternate method to assess scour depth in the Black Prairie Belt soil, a } \\
\text { consolidated, highly cohesive, organic clay within Alabama's Coastal Plain. } \\
\text { Envelope curves are presented based on observations of clear-water } \\
\text { contraction scour at } 25 \text { bridge sites. } \\
\text { Related link: http://pubs.usgs.gov/sir/2007/5260/ }\end{array}$ \\
\hline Illinois & $\begin{array}{l}\text { Illinois DOT permits reduction in scour depth computed by HEC } 18 \text { methods } \\
\text { for bridges founded in cohesive soil or rock. Such reductions are graduated } \\
\text { from } 0 \text { to } 100 \% \text {, depending on soil strength or degree of lithification of rock. } \\
\text { Related link: http://www.dot.state.il.us/bridges/brmanuals.html }\end{array}$ \\
\hline Maine & $\begin{array}{l}\text { This USGS Water Resources Investigations Report collected and analyzed } \\
\text { pier-scour data for eight bridges across Maine over a four year period. } \\
\text { Observed maximum scour depths were compared with predictions using the } \\
\text { CSU equation in HEC-18. The relation performed well for rivers in Maine, } \\
\text { and MaineDOT currently uses it for evaluation of existing and new bridges. } \\
\text { Related link: http://me.water.usgs.gov/reports/wrir02-4229.pdf }\end{array}$ \\
\hline $\begin{array}{l}\text { Pennsyl- } \\
\text { vania }\end{array}$ & $\begin{array}{l}\text { PennDOT scour design method recognizes the variable erosion behavior of } \\
\text { geologic materials in scour design. It establishes three classifications: sound } \\
\text { bedrock, erodible bedrock and coarse soil (gravel, cobbles and boulders), and } \\
\text { specific embedment depths and footing details are prescribed for each. } \\
\text { Related link: } \\
\text { ftp://ftp.dot.state.pa.us/public/PubsForms/Publications/PUB\%2015M.pdf }\end{array}$ \\
\hline $\begin{array}{l}\text { South } \\
\text { Carolina }\end{array}$ & $\begin{array}{l}\text { A recently published USGS Report of Investigation extends the earlier } 2006 \\
\text { USGS study described above in "Comparative Scour Studies." It } \\
\text { recommends use of envelope design curves to estimate scour depth. The } \\
\text { curves are rigorously justified with field observations and laboratory data. } \\
\text { SCDOT has incorporated the method into their latest scour design standards. } \\
\text { Related links: http://pubs.usgs.gov/sir/2009/5099/ } \\
\text { http://www.scdot.org/doing/pdfs/requirements2009.pdf }\end{array}$ \\
\hline Texas & $\begin{array}{l}\text { This comprehensive study performed by Texas Transportation Institute } \\
\text { summarizes a new method to assess a bridge for scour. It uses three levels of } \\
\text { bridge scour assessment (BSA } 1,2, \& 3 \text { ) and erosion classification charts. } \\
\text { Scour vulnerability is determined by comparing the predicted scour depth with } \\
\text { allowable scour depth of the foundation. The method is relatively simple to } \\
\text { apply, and it overcomes some of the over-conservatism in current methods. } \\
\text { Related link: http://tti.tamu.edu/documents/0-5505-1.pdf }\end{array}$ \\
\hline
\end{tabular}

NJIT Team has already reached several preliminary conclusions:

(1) The HEC 18 equations have led to excessively conservative design values for some state bridges. Revised computational procedures are needed to permit designers to adjust safety factors according to field performance and risk level.

(2) The bed materials in New Jersey's rivers are geologically diverse, and they often contain scour-resistant materials such as boulder trains, stiff clay, and shale. 
Revised analysis procedures are being developed to reflect New Jersey geology, which will reduce predicted scour depths for some sites.

(3) A review of the Stage II studies indicates that better standardization is needed in sampling and analysis of the stream bed materials. It appears that $D_{50}$ values used for analysis are biased towards finer grain sizes on account of wide use of surface grab sampling and lack of consideration for cobbles and boulders when present. In view of these findings, an important focus of the current study will be to develop a viable and uniform geotechnical sampling protocol so that scour analyses are based on a deeper vertical profile of actual stream bed sediments.

(4) The stream discharges used in the Stage II studies were developed using different methodologies (e.g. extreme value, regression analysis) and data from different agencies (e.g. FEMA, USSCS, USGS). Recently, the USGS has published a report (Watson and Schopp, 2009) providing an updated methodology for estimating flood magnitude and frequency for New Jersey streams, which reflects changes in factors such as impervious cover and population density. Differences between the flow data generated using the new USGS model and the original Stage II data are being investigated and assessed.

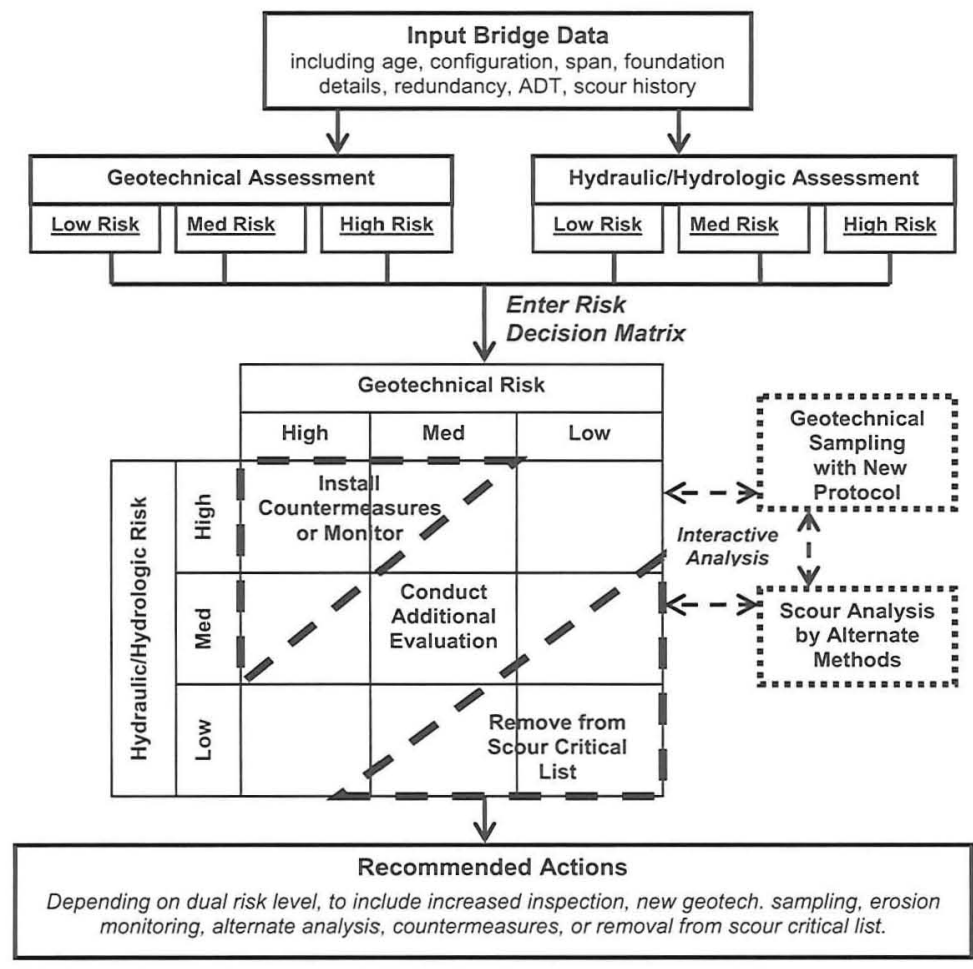

FIGURE 1: NJDOT Decision Matrix Model for Scour Evaluation 
A "Decision Matrix Model" is also being developed as part of NJDOT's scour research project. The tiered, risk-based model will allow the Department to reassess the bridges on the state's Scour Critical List. It is expected its application will better prioritize bridges and permit selection of more appropriate corrective actions. An abbreviated flowchart of the model is shown in Figure 1. The first step is to input relevant data including age, configuration, span, ADT and scour history. The next step is to perform geotechnical and hydraulic/hydrologic risk assessments using existing and new data. This information is the entered into the Risk Decision Matrix to determine overall scour risk. In the final step, one or more recommended actions are taken depending on risk level, which may include modification of inspection frequency, additional analyses, erosion monitoring, installation of countermeasures, or removal from the list.

\section{REFERENCES}

Benedict, S.T, N. Deshpande, N. M. Aziz and P.A. Conrads (2006). "Trends of Abutment-Scour Prediction Equations Applied to 144 Field Sites in South Carolina." USGS, OFR 2003-295, 1-131.

Froehlich, D.C. (1989). "Abutment Scour Prediction." Transportation Research Board Presentation, Washington, D.C.

Jain, S.C. and R.E. Fischer (1979). "Scour Around Bridge Piers at High Froude Numbers." FHWA Report No. FHWA-RD-79-104, USDOT, Wash. D.C.

Laursen, E.M. (1980). "Predicting Scour at Bridge Piers and Abutments." General Report No. 3, Arizona Dept. of Transportation, Phoenix, AZ.

Lombard, P.J. and G.A. Hodgkins (2008). "Comparison of Observed and Predicted Abutment Scour at Selected Bridges in Maine." USGS SI Report 2008-5099, 1-29.

Melville, B.W. (1992). "Local Scour at Bridge Abutments." Journal of Hydraulic Engineering, ASCE Hydraulics Division, 118(4).

Richardson, E.V., and S.R. Davis (2001). Evaluating Scour at Bridges, (4th ed.): Federal Highway Administration Hydraulic Engineering Circular (HEC) 18, Publication FHWA-NHI 01-001, 378 p.

Richardson, E.V., D.B. Simons, and P.F. Lagasse (2001). "River Engineering for Highway Encroachments - Highways in the River Environment." FHWA Report NHI 01-004, Hydraulic Series No. 6, Washington, D.C.

Sturm, T.W. (1999). "Abutment Scour in Compound Channels." Stream Stability and Scour at Highway Bridges, ASCE Compendium, Richardson and Lagasse (eds.), Reston, VA.

Wagner, C.R., D.S Mueller, A.C. Parola, D.J. Hagerty, \& S.T Benedict (2006).

"Scour at Contracted Bridges." NCHRP-TRB, Doc. 83 (Project 21-14).

Watson, K.M., and R.D. Schopp (2009). "Methodology for Estimation of Flood Magnitude and Frequency for New Jersey Streams." USGS, SI Report 2009-5167, 1-51. 